\title{
STRATEGI PENGEMBANGAN KOPERASI INDONESIA MENUJU KOPERASI MANDIRI
}

\author{
Salim Al Idrus \\ Fakultas Ekonomi Universitas Islam Negeri Maulana Malik Ibrahim Malang \\ Jl. Gajayana No. 50, Telepon (0341) 558881, Fax. (0341) 558881, \\ E-mail: feuinmlg@yahoo.co.id
}

\begin{abstract}
Cooperation is a social enterprise which its existence should be developed in order to create economic democartion. Cooperation has to act as a counterpart to otherside which power is concentrated on certain groups. More over, as a base of national economic, cooperation not only becomes an institution which members are small scale indutries, buat also becomes an absolute economic power in determining national economic's power and behavior it self. In realizing it, cooperation must have an ability to become an atunomous institution outisde the government. Having a clear "core business", cooperation will get the benefit by exploiting business power in its scope. If it is reached, cooperation will become one of the independent economic actors. This independence will make the cooperation developes better than ever. On the other side, cooperation must still have bottom-commitment to the society who has it.
\end{abstract}

Key words: cooperation, social enterprise, independent economic

Ada pertanyaan menarik sekitar perkembangan koperasi Indonesia yang kerap sulit dijawab secara tepat. Sudah seberapa jauh koperasi mampu memainkan peranannya sebagai sokoguru perekonomian nasional? Lebih jauh lagi, berapa besar kontribusi koperasi terhadap pertumbuhan produk domestik bruto (PDB) ataupun pemerataan hasil-hasil ekonomi? Cukup alasan mengemukakan pertanyaan itu karena selama setengah abad lebih Indonesia merdeka, koperasi ternyata belum mampu memperoleh tempat terhormat sebagai lembaga ekonomi dalam percaturannya bersama-sama dengan Badan Usaha Milik Negara (BUMN) dan Badan Usaha Milik Swasta (BUMS).

Berdasarkan data resmi pemerintah, kiprah koperasi secara kuantitatif menunjukkan grafik yang terus meningkat. Aktivitas koperasi berkembang di berbagai wilayah nusantara. Namun secara kualitatif, pertumbuhan koperasi masih perlu dipertanyakan. Tanpa bermaksud memperbandingkan hasil usaha 
koperasi dengan BUMN atau BUMS, fakta menunjukkan bahwa nilai kontribusi koperasi dibandingkan dengan kedua pelaku ekonomi tersebut masih jauh tertinggal. Masih rendahnya nilai pendapatan ekonomis koperasi tersebut menempatkan lembaga ini hanya menjadi sektor marjinal dalam perekonomian nasional dan keberadaannya pun kadang kurang diperhitungkan.

Persoalannya, koperasi sebagai business and social entity hingga kini masih terbelenggu dengan ide-ide besar social welfare economic, sebuah cita-cita luhur membangun masyarakat sejahtera dengan basis ekonomi gotong royong dan kekeluargaan. Kerangka ekonomi ideal-normatif seperti diamanatkan dalam Pasal 33 UUD 1945 itu nyatanya sering gamang ketika berhadapan dengan realitas sistem ekonomi (liberal-kapitalis) yang berkembang. Kegamangannya itu terutama tampak dari ketidakberdayaan anggotanya saat menghadapi tantangan ekonomi global. Beberapa akses bisnis yang mestinya jadi lahan subur koperasi terutama agribisnis dan agroindustri hanya tergarap pada sektor pinggiran. Dalam pengelolaan bahan baku menjadi bahan industri, misalnya sumber daya manusia koperasi kurang pula berdaya. Akibatnya, nilai tambah ekonomi koperasi di sektor pertanian relatif lebih rendah dibanding dominasi swasta yang menguasai jalur industri dan ekspor.

Secara struktural, koperasi memiliki akses paling kecil terhadap faktor produksi, khususnya permodalan, dibanding dengan pelaku ekonomi lainnya. Padahal kita mengetahui bahwa tingkat penguasaan faktor produksi berkorelasi positif dengan tingkat pemanfaatan hasil pembangunan. Oleh karena itu, wajar saja jika sumbangan koperasi terhadap PDB saat ini masih sangat kecil.

Selain itu secara institusional koperasi memiliki ruang gerak yang paling terbatas dibanding dengan pelaku usaha tidak memungkinkan koperasi bergerak bebas seperti swasta murni. Itu sebabnya, selama ini kegiatan usaha koperasi hanya seputar simpan pinjam dan pertokoan. Padahal sebenarnya, banyak peluang yang mampu digarap koperasi dan dapat memberikan manfaat lebih besar kepada anggotanya. Tetapi karena hambatan tadi, koperasi tidak dapat memanfaatkan peluang tersebut. secara de jure dan de facto, sistem perekonomian Indonesia berlandaskan atas teori keseimbangan, yaitu keberhasilan dalam mewujudkan cita-cita masyarakat adil dan makmur hanya dapat dicapai dengan adanya keseimbangan peran di antara tiga pelaku ekonomi nasional, yaitu 
BUMN, BUMS dan Koperasi. Tanpa keseimbangan itu, sulit untuk dapat mewujudkan cita-cita tersebut.

Dilihat dari kenyataan yang ada di antara tiga pelaku ekonomi tersebut, hanya koperasi yang berperan dominan sebagai wahana ekonomi kelompok masyarakat ekonomi lemah. Oleh karena itu, keberadaan koperasi sebagai pelaku ekonomi nasional sebenarnya lebih merupakan representasi dari golongan ekonomi lemah. Sehingga wjarlah jika para pendiri republik ini mencantumkan koperasi dalam UUD 1945 sebagai wahana dalam pencapaian cita-cita masyarakat adil dan makmur.

Karenanya tidak keliru jika dikatakan keberadaan koperasi Indonesia dalam konteks kelembagaan dan pengembangan usaha masih dalam upaya pencarian dan penyesuaian yang pas dalam sistem ekonomi yang berlangsung. Dalam plot semacam ini, perjalanan koperasi cukup banyak menjumpai kendala internal dan eksternal.

\section{MASALAH YANG DIHADAPI}

Setelah 30 tahun lebih membangun, kita mengakui bahwa struktur ekonomi nasional belum sesuai dengan harapan. Struktur ekonomi yang terjelma masih sangat "berat ke atas", masih amat bergantung kepada sekelompok kecil pengusaha-pengusaha besar. Struktur ekonomi semacam itu mengundang kerawanan-kerawanan. Satu dua perusahaan besar terguncang, dampaknya akan terasa amat luas. Hal ini telah terbukti dengan adanya krisis moneter yang melanda Indonesia sejak media 1997 sampai saat ini belum menunjukkan tandatanda akan berakhir. Sesuatu yang normal, karena kita memiliki cukup penyangga. Di banyak negara, penyangga itu berbentuk dari anyaman kekuatan ekonomi kecil dan menengah.

Untuk kita memerlukan komitmen yang lebih jelas, tanpa perlu memperhatikan antara kepentingan pertumbuhan dan pemerataan. Penumbuhan kesempatan berusaha bagi koperasi tak ubahnya bagai sepenggal roti. Dipotong, inti bisnisnya diberikan kepada swasta dan BUMN, remahremahnya baru diberikan kepada koperasi (Suryono dan Muchtar, 1996). Kondisi demikian dapat dimaklumi, karena dalam banyak hal memang koperasi masih terbatas kemampuannya dalam menyerap dan mengantisipasi perubahan dan 
perkembangan dunia bisnis yang senantiasa menuntut pengelolaan yang profesional.

Bila ditelusuri ada sejumlah faktor yang menyebabkan perkembangan koperasi masih jauh dari cita-cita kemerdekaan. Penyebab tersebut ada yang melekat pada koperasi itu sendiri (kendala internal) dan ada yang berada di luar batang tubuh koperasi (kendala eksternal).

Kendala internal dapat dilihat dari beberapa aspek. Pertama, kendala kelangkaan sumber daya profesional untuk mengelola organisasi maupun koperasi. Seperti kita ketahui, sumber daya manusia dalam bentuk tenaga profesional di tanah air kita jumlahnya masih terbatas, sementara kebutuhan terhadap tenaga seperti itu sangat tinggi.

Kedua, kendala keterbatasan sumber kapital swadaya. Sebagaimana diketahui sebagian besar anggota koperasi terdiri dari dari kalangan ekonomi menengah ke bawah. Kondisi ini merupakan kendala tersendiri bagi koeprasi untuk memupuk modal swadaya anggota yang relatif rendah. Di lain pihak untuk mengakumulasi modal dan pendapatan usaha juga tidak mudah, karena skala usaha koperasi yang kecil.

Ketiga, masih rendahnya kesadaran berkoperasi di kalangan anggota. Ini erat kaitannya dengan latar belakang anggota dan pengelola koperasi. Di satu pihak tingkat pendidikan anggota dan pengelola pada umumnya masih rendah, menuntut cara-cara tertentu agar mereka menjadi lebih paham bagaimana seharusnya berkoperasi. Di lain pihak keterbatasan tenaga terampil juga mengakibatkan rendahnya kemampuan pengelola koperasi dalam memberikan pengertian berkoperasi secara efektif kepada anggota dan masyarakat.

Dilihat dari sisi eksternal juga ada beberapa kendala yang cukup menonjol yang menyebabkan masih lambannya perkembangan koperasi. Pertama, persepsi pentingnya dalam proses pembangunan nasional masih belum sama baik di kalangan pemegang kebijakan maupun para pelaku ekonomi dan masyarakat pada umumnya. Berbagai persepsi tentang peran koperasi lebih terlihat lagi dalam aplikasi kegiatan ekonomi di lapangan. Kadangkala muncul pertanyaan di masyarakat, yang penting badan hukum koperasinya atau kebersamaannya? 
Kedua, perhatian lembaga keuangan masih sangat rendah. Hal ini bila dilihat dari sisi ekonomi wajar-wajar saja, karena koperasi yang layak secara ekonomi dilihat dari kacamata perbankan jumlahnya masih sangat kecil dibandingkan dengan usaha lain.

Ketiga, iklim usaha yang kurang kondusif bagi kegiatan koperasi. Iklim ini berkaitan dengan kondisi koperasi yang ada sekarang, dimana koperasi masih sangat sarat dengan kendala internasional maupun eksternal. Dalam kondisi ini sangat diperlukan kondisi khusus dari koperasi. Dengan orientasi ekonomi pasar saat ini, koperasi akan semakin tertinggal dalam bersaing dengan badan usaha lain, khususnya dengan telah timbulnya monopoli dan oligopoli pasar menyebabkan koperasi semakin tersisih dari percaturan bisnis.

Keempat, aturan-aturan yang ada untuk koperasi terasa kaku dan mengungkung, mempersulit ruang gerak koperasi, seperti aturan sumber modal, aturan wilayah kerja, proses pembentukan dan sebagainya. Di lain pihak untuk badan usaha swasta aturan terasa sangat lentur dan cukup mempermudah ruang gerak badan usaha tersebut.

Dalam menghadapi situasi bisnis dewasa ini, dimana perekonomian dunia cenderung tak menentu, kehadiran koperasi yang benar-benar mandiri sangat diperlukan. Kehadiran koperasi sebagai kegiatan ekonomi rakyat dan sebagai salah satu pelaku ekonomi diharapkan akan mampu memberikan poin tersendiri dalam usahanya untuk memecahkan permasalahan nasional yang timbul yaitu kesempatan kerja, peningkatan pendapatan masyarakat, serta pemerataan pembangunan.

\section{STRATEGI PENGEMBANGAN}

Koperasi dalam realitas jarang sekali menjadi besar dan maju. Lembaga ini sering berhenti sebagai unit-unit ekonomi kolektif yang kecil dan lambat. Malahan di sementara kalangan masyarakat terdapat krisis ketidakpercayaan. Maka tak perlu heran, bila koperasi masih lebih banyak di alam cita-cita, baik cita-cita untuk menjadikannya sebagai bagian sendi atau sokoguru sistem perekonomian Indonesia sebagai diamanatkan UUD 1945 tersebut, maupun sebagai wadah kegiatan ekonomi rakyat yang numeratif seperti yang diinspirasikan oleh gerakan koperasi dalam masyarakat. 
Dalam kerangka ini mengkaji kembali koperasi lewat salah satu sendi dasarnya, yaitu asas swadaya (kemandirian) agaknya menjadi sangat relevan karena di sini ditemui bahwa lemahnya swadaya/kemandirian dengan maju mundurnya perkembangan koperasi mempunyai korelasi yang signifikan.

Dengan melihat bahwa kegiatan koperasi didasarkan pada prinsip swadaya atau kemandirian, maka modal paling utama adalah kepercayaan dan keyakinan, bahwa masyarakat manusia betapapun terbelakangnya, mempunyai potensi untuk mengembangkan dan memajukan kehidupan sendiri secara dinamis, walaupun kita tidak menolak adanya perbedaan dalam akselerasi. Oleh karena itu, swadaya atau kemandirian di sini tidak dapat diartikan secara sempit dalam bentuk materialnya saja (kemampuan membentuk modal sendiri) namun juga dalam wujud mental spiritual (kemampuan untuk membentuk sikap setia kawan dan kesadaran pribadi).

Dengan demikian, kemandirian sesungguhnya berakar pada sikap manusia sendiri. Oleh karena itu, kita berasumsi bahwa kemandirian berakar pada sikap manusia, maka pengembangan kemandirian dalam konteks ini berarti usaha mengubah sikap warga koperasi untuk yakin dan percaya bahwa sebagai individu mereka mempunyai kemampuan untuk memperbaiki dirinya melalui kerjasama dan kesetiakawanan dalam wadah koperasi. Dan pada rangkaian berikutnya pengembangan peran serta dan kerjasama atas dasar kesetiakawanan inilah yang merupakan langkah kunci yang harus diambil oleh setiap koperasi jika ingin menjadi nafas bagi setiap insan Indonesia dalam menjalankan roda perekonomian.

Namun patut kita perhatikan pula, bahwa praktik kemandirian tak berarti secara apriori menolak atau mengesampingkan bantuan dari pihak ketiga. Justru dalam perkembangan bertahap menuju posisi mandiri yang lebih mantap adakalanya dibutuhkan bantuan dan dorongan dari pihak ketiga, misalnya saja kredit. Asas kemandirian koperasi bukan berarti (tidak sama) dengan anti kredit. Strategi lembaga ekonomi, di samping idealismenya yang ingin mengembangkan rakyat kecil, koperasi mestinya harus mempertimbangkan kaidah-kaidah usaha ekonomis profesional, karena itu kredit bagi koperasi hendaknya tidak ditafsirkan sebagai satu hal yang melemahkan kemandirian koperasi, melainkan justru bersifat merangsang 
perkembangan atau menutup kekurangan modal yang tak mampu dipikul sendiri dengan simpanan para anggota untuk suatu usaha dengan tingkat kelayakan ekonomis dan sosial yang tinggi.

Hanya saja praktik kemandirian menuntut sikap percaya pada diri terlebih dahulu, kembali diawali dengan pemupukan modal dari dalam sebagai cerminan untuk mengukur tingkat kadar self-financing. Dalam hubungan ini, maka bantuan dari luar harus didasarkan persentase tertentu dari modal dan kemampuan manajemen serta mempertimbangkan aspek kelayakan dan kemampuan menanggung risiko. Penerapan kebijaksanaan yang mendukung perlu kiranya dilakukan dalam upaya pengembangan koperasi ke arah mandiri yang benar-benar diharapkan khususnya dalam menyongsong era pasar bebas ke depan.

Beberapa kebijaksanaan tersebut adalah sebagai berikut: (1) iklim usaha yang kondusif; (2) pendekatan bisnis pada koperasi; (3) peningkatan partisipasi anggota; (4) peningkatan pemahaman masyarakat dan (5) pengurangan intervensi pemerintah.

Untuk menjawab pertanyaan-pertanyaan ini yang sekaligus masih menjadi masalah di seputar koperasi kita, dalam berbagai tujuan praktikalnya koperasi harus diberlakukan sebagai organisasi bisnis. Insentif, bantuan dan perlindungan terhadapnya hanya bersifat sementara agar koperasi tersebut tumbuh mandiri (self reliance).

Pendekatan bisnislah yang akan mengeliminasi dan memperbaiki kondisi inefisiensi dan inefektivitas koperasi saat ini. Hanya saja penekanan saat ini tertuju pada prinsip sosialnya. Namun ketika aspek ekonominya diabaikan, koperasi pun akan sulit mencapai tujuannya, yaitu kesejahteraan rakyat.

Koperasi tidak harus dipandang eksklusif dalam sistem ekonomi dan sosial secara keseluruhan, dan sejalan dengan perkembangan pertanian, industri dan perekonomian secara umum, tingkat persaingan pun akan semakin meningkat. Penemuan teknologi dan perbaikan pasar akan semakin mengefektifkan orang ekonomi. Tanpa tanggap terhadap perkembangan yang terjadi, jangan diharap koperasi akan hadir sebagai lembaga ekonomi yang akan mampu memperkokoh ketahanan ekonomi kita. 
Dalam hal ini, koperasi pun mempunyai peranan yang sama dengan lembaga-lembaga ekonomi lainnya. Tidak hanya melayani anggota, tetapi koperasi pun harus hadir sebagai lembaga profesional, untuk menerapkan bahkan menemukan inovasi, metode dan pencairan pasar-pasar yang baru. Dari peran seperti inilah kita boleh berharpa koperasi kita akan dapat memberikan suatu kontribusi terhadap perekonomian secara menyeluruh.

Untuk dapat merealisasi dan mengkondisikan koperasi sebagai organisasi bisnis diperlukan manajer yang berkualitas, berjiwa wiraswasta, punya keterampilan manajerial, penuh pengabdian dan dedikasi akan membawa koperasi kepada kemajuan dan keberhasilan (Wirasastmita, 2000). Dari pengalaman empiris terlihat bahwa umumnya manajer koperasi kurang gigih berpromosi dan kurang melakukan continous education of members kepada anggota. Hal ini disebabkan antara lain karena para manajer itu terlalu berpikir idealis dan tinggi, kurang turun ke dunia nyata, sehingga hal-hal yang praktis kurang dilaksanakan (Sutojo, 1995).

\section{PENINGKATAN PARTISIPASI ANGGOTA}

Corak persaingan bisnis sekarang ini memang sudah bertambah luas perspektifnya. Perusahaan-perusahaan non koperasi dalam strategi bisnisnya bukan lagi sekedar mencari konsumen dan merebut pelanggan, tetapi juga menciptakan "kepuasan pelanggan". Dengan kata lain, fanatisme pelanggan sudah menjadi tumpuan utama bagi keunggulan kompetitif (competitive advantage) dan ketahanan (survival) perusahaan. Hal ini mengisyaratkan bisnis yang dihadapi koperasi sudah menyangkut persoalan bagaimana mempertahankan dan memelihara kesetiaan anggota yang notabene adalah pemilik dan pelanggan koperasi.

Menghadapi corak persaingan demikian, tak ada jalan lain kecuali dimulai dan bertumpu pada dua unsur substansial koperasi itu sendiri: partisipasi anggota dan efisiensi usaha. Tumbuhnya partisipasi anggota sangat ditentukan oleh kemampuan koperasi untuk mengintegrasikan usaha atau kepentingan ekonomi anggota secara layak dan mengelolanya secara efektif dan efisien. Sebaliknya, dengan pengelolaan yang efisien, koperasi dapat 
memberikan inisiatif yang layak kepada anggotanya dan dapat memupuk modal.

Dua unsur tersebut tidak dapat dipisah-pisahkan. Bagaikan dua sisi dalam satu koin. Partisipasi anggota dalam proses pengambilan keputusan, kegiatan usaha dan dalam mekanisme pengawasan merupakan pencerminan praktis dalam prinsip-prinsip koperasi. Sedangkan efisiensi usaha yang sesuai dengan kaidah-kaidah bisnis yang rasional adalah konsekuensi logis yang harus dilakukan koperasi agar ia dapat memberikan insentif kepada anggotanya, dan dapat tumbuh di tengah lingkungan usaha yang berdasarkan pada hukum ekonomi pasar.

Dari pengalaman empiris memperlihatkan, bahwa banyak anggota koperasi kurang sadar, tidak berpartisipasi, menekankan kepentingan sendiri, tidak disiplin, dan nada lain yang sifatnya negatif. Akibatnya banyak pengurus/manajer yang berpaling pada sumber di luar para anggotanya untuk memenuhi kebutuhan permodalan atau sarana yang lain bagi koperasinya. Mekanisme komunikasi yang timpang antar pengelola dengan anggota koperasi ini tidak pernah dituding sebagai biang keladi rendahnya partisipasi anggota.

Tak perlu ditutupi lagi, bahwa di dalam masyarakat sekarang ini arus konsumerisme yang amat kompetitif seringkali menggoyahkan para pengelola dan anggota untuk tetap tegak mengatur pola hidup dan berusaha atas dasar kemampuan sendiri. Berbagai iklan yang menawarkan hadiah yang menggiurkan banyak membuat anggota koperasi berpaling ke sumber lain yang memang dirasa lebih memuaskan.

\section{PENINGKATAN PEMAHAMAN MASYARAKAT}

Makna koperasi terletak dalam kemampuannya untuk meningkatkan harkat dan martabat kehidupan sosial-ekonomi lapisan masyarakat bawah. Dalam konteks ini sebenarnya koperasi merupakan suatu lembaga yang sangat krusial dalam proses pembangunan. Mengapa demikian? Koperasi dapat memberikan sumbangan bagi promosi pembangunan dengan jalan menyediakan informasi yang sangat berisi mengenai kondisi loka/setempat/desa maupun kemungkinan-kemungkinan dari apa yang dapat dilakukan oleh badan-badan pemerintah. Di samping itu, koperasi dapat menyesuaikan kebijakan-kebijakan 
dan prioritas-prioritas umum dengan kebutuhan-kebutuhan dan keadaankeadaan tertentu. Dalam hal ini, koperasi dapat berperan serta dalam perencanaan pembangunan dan penetapan tujuan pembangunan.

Koperasi dapat memainkan peranan penting dalam memberikan input produksi dan pelayanan yang diperlukan oleh para anggotanya maupun input dan pelayanan yang berasal dari berbagai saluran dan sistem lembaga. Selain itu, koperasi dapat meningkatkan kemampuan anggotanya dalam berorganisasi secara efektif, sehingga para anggotanya mempunyai kesempatan yang besar dalam mengartikulasikan kebutuhan-kebutuhan dan tuntutan hidup.

Kendatipun demikian, koperasi masih lemah dalam memainkan peranan yang bermakna dalam proses pembangunan. Segudang masalah menghadangnya. Terdapat citra tentang pengurus yang tidak dapat dipercaya. Skala usaha koperasi masih kecil. Koperasi masih kekurangan tenaga pengelola yang profesional. Sebagian besar koperasi masih menggunakan cara produksi yang masih bersifat tradisional, dengan kemampuan pemasaran yang masih lemah. Kemampuan untuk mengakumulasi modal juga rendah. Lebih dari itu, cap yang melekat pada koperasi selama ini adalah bahwa koperasi hanyalah alat untuk melancarkan program pemerintah.

Pada umumnya kenyataan menunjukkan bahwa paham koperasi masih belum tumbuh dan berkembang dari bawah sebagai semangat yang diharapkan dalam kegiatan ekonomi. Hal ini masih telihat dari rendahnya peran serta masyarakat dalam koperasi. Untuk itu dalam upaya membentuk koperasi yang mandiri pemberian pemahaman kepada masyarakat tentang koperasi mutlak perlu.

Perlunya pemberian pemahaman tentang berkoperasi kepada anggota dan masyarakat ini karena koperasi adalah organisasi ekonomi rakyat yang bertujuan meningkatkan pendapatan rakyat. Masyarakat di lingkungan koperasi masih senantiasa harus diberi penyuluhan tentang peran dan fungsinya, karena tingkat pendidikan dan pengetahuan mereka masih rendah.

Kadangkala untuk memberikan pengertian berkoperasi yang baik pada masyarakat tidaklah terlalu sulit, cukup dengan memperlihatkan keberhasilan pengelola koperasi dalam menangani kegiatan organisasi dan usaha yang berorientasi pada kepentingan anggota. Khususnya kepada masyarakat yang 
berpendidikan rendah, cara ini adalah yang paling efektif jika dibandingkan dengan penyuluhan.

Dengan keberhasilan koperasi biasanya anggota secara bertahap dan dengan sendirinya mengerti bagaimana seharusnya berkoperasi yang baik. Pada gilirannya masyarakat akan lebih tertarik menjadi anggota koperasi. Apabila hal ini berlangsung secara kontinu adalah hal yang tidak sulit bagi koperasi untuk berkembang maju. Namun kenyataan di lapangan masih sangat sulit menemukan koperasi yang berhasil. Kejadian yang sering ditemui di lapangan bahkan sering sebaliknya, yang berakibat menjauhnya masyarakat dari koperasi.

\section{PENGURANGAN INTERVENSI PEMERINTAH}

Pada prinsipnya intervensi pemerintah ini tidak lain dimaksudkan untuk membantu proses pengembangan koperasi agar lebih maju dan berkembang. Tetapi kenyataannya di lapangan menunjukkan bahwa adanya intervensi pemerintah yang berlebihan membuat gerakan koperasi kian tercecer dalam laju pertumbuhan ekonomi nasional. Intervensi ini mulai dari proses pendirian, pengelolaan usaha, pengurusan kredit, hingga pengembangannya nyaris tidak mendorong kreativitas dan inisiatif anggota.

Karenanya, bukan rahasia lagi jika kenyataan menunjukkan loyalitas pengurus bukan ke bawah (kepada anggotanya) tapi malah ke atas (orang yang mengangkatnya). Sudah bukan rahasia lagi jika pemilik cenderung tunduk kepada Kepala Kantor Koperasi daripada Puskud. Pembinaan seperti inilah akhirnya memecah belah hubungan koperasi primer dan sekunder. Akibatnya, koperasi bukannya tumbuh sebagai badan usaha tetapi lebih sebagai jaringan paling ujung dari kegiatan birorkasi pemerintah.

Intervensi dalam penetapan pengurus juga mengandung risiko yang besar. Selain memerlukan mekanisme kontrol terhadap aktivitas pengurus yang bukan berasal dari anggota, pengurus "dropping" ini akan berdampak negatif terhadap kepercayaan dari anggota.

Akibat negatif dari kebijakan pemerintah terhadap koperasi ini paling tidak ada dua. Pertama, secara nyata tercipta situasi saling ketergantungan pada pemerintah, dan ketergantungan yang sifatnya simetris pada koperasi telah membawa pada "oedipus complex". Kedua, telah terbentuk pula citra bahwa 
koperasi adalah alat pemerintah bahkan kepanjangan dari aparatur pemerintah di dalam masyarakat.

Intervensi aparatur/pejabat pemerintah merupakan salah satu penyebab utama menipisnya swadaya koperasi. Memang secara formal tidak nampak, namun secara aktual di lapangan sangat banyak dan sangat mendalam. Intervensi pejabat dirasakan mulai dari pembentukan koperasi, yang seharusnya dan secara formal memang dilakukan oleh para anggota. Tentang seleksi para anggota sampai pada pertanggungjawaban keuangananpun yang seharusnya dipilih dan dilakukan oleh para anggota, tak luput dari intervensi pemerintah. Malahan kadang sampai pembangunan kantor dan peralatan.

Pola pendekatan top-down yang dilakukan selama ini menyebabkan kurangnya inisiatif dan peran serta yang bermakna dari masyarakat lapisan bawah dalam koperasi. Koperasi yang ditumbuhkan dari atas, yang bagi masyarakat desa misalnya merupakan suatu inovasi yang sangat kompleks dan sulit dibudayakan dalam kalangan penduduk desa. Konsekuensinya koperasi desa (KUD) cenderung merupakan lembaga yang memberikan pelayanan bukan sebagai usaha yang mampu mendorong sendiri (self-propelling undertakings) yang mendapat dukungan dari masyarakat des secara luas.

Kurangnya inisiatif dan peran serta yang bermakna dari penduduk desa lapisan bawah merupakan indikator kuat bahwa evaluasi pembuatan keputusan dari tingkat pemerintah yang lebih tinggi ke lembaga-lembaga desa sangat rendah. Hal ini mengurangi keefektifan koperasi dalam memperbaiki kesejahteraan penduduk lapisan bawah.

\section{KESIMPULAN}

Lebih dari 30 tahun kita membangun, BUMN berkembang dengan semakin sehat, termasuk di dalamnya usaha-usaha swasta. Pengusaha besar pun bermunculan dengan omset-omset yang sangat menggiurkan. Lain halnya dengan koperasi. Usaha koperasi saat ini di persimpangan jalan. Di satu pihak ada koperasi yang ingin mengikuti perusahaan-perusahaan raksasa, sedang di pihak lain ada juga koperasi yang tetap berusaha pada kaidah-kaidah perkoperasian, yang lebih mengutamakan pelayanan kepada anggota, meski di luar harus menghadapi berbagai masalah dan kesulitan-kesulitan untuk 
mempertahankan kehidupannya yang dapat mengarahkan pada krisis ideologi, kepemimpinan, dan kepercayaan dalam jajaran perkoperasian.

Dalam upaya pengembangan koperasi ke depan, bukan saja peranan pemerintah yang menentukan perkembangannya, tetapi juga masyarakat itu sendiri yang ikut menentukan berkembang atau tidaknya suatu koperasi, baik sebagai anggota koperasi maupun sebagai anggota masyarakat yang berada dalam ruang lingkup koperasi tersebut.

Hal ini dapat dimaklumi, mengingat koperasi merupakan suatu organisasi ekonomi yang terdiri dari kumpulan orang-orang yang secara bersama-sama dan sukarela memajukan kepentingan ekonomi baik anggotanya dan masyarakat dalam lingkungan kerjanya. Dan karena koperasi merupakan sekumpulan orang yang berusaha untuk mencapai tujuan yang telah diprogramkan bersama, sudah barang tentu perkembangannya bergantung pada orang-orang atau masyarakat yang menjadi pengurus dari pengelolanya, maupun hanya sebagai anggota biasa.

Eksistensi koperasi dalam sistem ekonomi nasional memang selalu terkait dengan faktor kuantitas dan kualitas koperasi dengan jumlah yang banyak, tetapi bila tidak diikuti oleh kemampuan kualitas yang memadai, maka kita sulit mengharapkan peran yang lebih besar dari koperasi dalam pengembangan ekonomi di tanah air. Proses restrukturisasi dan revitalisasi ekonomi nasional harus dapat menjadikan koperasi sebagai ujung tombak, sebagai tujuan utama dalam rangka pemerataan pendapatan, peningkatan kualitas hidup dan derajat kehidupan mereka di tengah-tengah pembangunan nasional.

\section{DAFTAR PUSTAKA}

Suyono, A.G. dan Muchtar, I. dkk. 1996. Koperasi dalam Sorotan Pers. Jakarta: Pustaka Sinar Harapan.

Anaroga, P. dan Widiyanti, N. 1992. Dinamika Koperasi. Jakarta: Rineka Cipta.

Damanhuri, D. 1996. Konglomerat, Kesenjangan dan Persaingan Global. Media Indonesia, Oktober 1996.

Rachbini, D.J. 1998. Koperasi Pendekatan Bisnis dan Politik. Kompas, Maret, 1998. Ropke, J. 2000. Ekonomi Koperasi. Jakarta: Salemba Empat. 
Sutojo, H. 1995. Mencari Terapi Pembinaan Koperasi di Perkotaan. Warta Koperasi, No. 61 Tahun XIV.

Sumual, D.E. 1998. Ekonomi Politik Perkoperasian Indonesia. Manajemen Usahawan Indonesia, No. 07 Tahun XXVII.

Mubyarto. 1997. Ekonomi Rakyat, Program IDT dan Demokrasi Ekonomi Indonesia. Yogyakarta: Aditya Media.

Wirasasmita, Y. 2000. Pengembangan Kewirausahaan di Lingkungan Koperasi, Makalah, Juni. 